\title{
Pikkuvasikoiden kasvatus eristämättömissä olosuhteissa - kirjallisuusselvitys
}

\author{
Leena Tuomisto ja Arto Huuskonen \\ Maa- ja elintarviketalouden tutkimuskeskus, Kotieläintuotannon tutkimus, Halolantie 31 A, 71750 \\ Maaninka,etunimi.sukunimi@mtt.fi
}

\section{Tiivistelmä}

Tämän kirjallisuusselvityksen tarkoituksena oli koota tutkittua tietoa pikkuvasikoiden lämmönsäätelyn fysiologiasta ja kylmässä kasvattamisen vaikutuksesta pikkuvasikoiden terveyteen, tuotantoon ja hyvinvointiin. Vasikat ovat vanhempia eläimiä heikommin varustettuja selviytymään äärilämpötiloissa. Kyky sietää alhaisia lämpötiloja kehittyy vasikan kasvaessa. Iän myötä vasikan lämpöeristys paranee: karvapeite tihenee ja pitenee, iho paksunee ja ihonalainen rasva lisääntyy. Termoneutraalilla alueella vasikka säilyttää ruumiinlämpönsä tasaisena pelkästään fysikaalisen lämmönsäätelyn keinoin vähentämällä tai lisäämällä elimistöstä tapahtuvaa lämmönhukkaa. Tämä tapahtuu säätelemällä iholle virtaavan veren määrää, sydämen sykettä, hengitystiheyttä ja ihon karvojen asentoa. Alemman kriittisen lämpötilan alapuolella vasikan on myös lisättävä aineenvaihdunnallista lämmöntuottoaan säilyttääkseen tasaisen ruumiinlämpötilansa. Tämä tapahtuu lihasvärinällisen ja lihasvärinättömän (ruskean rasvakudoksen aktivoituminen) lämmöntuoton avulla. Maksimaalisen lämmöntuoton ollessa käynnissä vastasyntyneen vasikan energiavarastot kuluvat loppuun noin 18 tunnissa. Lihasvärinä lakkaa vasikan ydinlämpötilan laskettua $6-8{ }^{\circ} \mathrm{C}: 11 \mathrm{la}$. Ruumiinlämmön edelleen laskiessa vasikka kuolee. Suomen nykyisen eläinsuojelulainsäädännön mukaan vasikat on totutettava kylmäkasvatukseen vähitellen. Vasikoilla on oltava asianmukaiset ruokinta- ja juoma-astiat, sulaa juomavettä sekä kuivikepohjainen suoja epäsuotuisia sääolosuhteita vastaan. Pikkuvasikoiden kasvua ja rehunkäyttöä kylmissä olosuhteissa on tutkittu melko laajasti ristiriitaisin tuloksin. Vasikat ovat kasvaneet heikommin, yhtä hyvin tai jopa paremmin kylmissä kuin lämpimissä olosuhteissa. Kylmissä olosuhteissa kasvatus on lisännyt vasikoiden rehun syöntiä tai ei ole vaikuttanut siihen. Talvella vasikan rehunkulutuksen on laskettu olevan 3-4 \% suurempi eristämättömässä kuin eristetyssä kasvatusympäristössä. Eläimestä tapahtuva lämmönhukka on pienin asennoissa, joissa vartalon lämpöä luovuttava pinta-ala on mahdollisimman pieni. Kylmissä oloissa vasikat voivat vähentää lämmönhukkaansa ja säästää energiaa lisäämällä kokonaismakuuaikaa sekä makaamalla enemmän käpertyneenä ja kiinni toisessa eläimessä. Ulkokasvatuksen vaikutusta vasikoiden terveyteen on tutkittu paljon. Iglukasvatuksen on usein havaittu vähentävän hengitystietulehduksia ja ripulia verrattuna sisäkasvatukseen, mutta vastakkaissuuntaisiakin tutkimustuloksia on saatu.

Asiasanat: vasikat, tuotantoympäristöt, kylmäkasvatus, iglut, lämmönsäätely, tuotanto, terveys 


\section{Johdanto}

Pohjois-Amerikassa ja Keski-Euroopassa vasikkaterveyttä pyritään kohentamaan siirtämällä vasikat varhaisessa vaiheessa ulkokasvatukseen tai eristämättömiin vasikkatiloihin. Suomessa pikkuvasikoiden ulkokasvatus on kuitenkin melko uusi kasvatusmuoto ja sitä harjoitetaan vain muutamilla tiloilla. Tämän kirjallisuusselvityksen tarkoituksena oli koota tutkittua tietoa pikkuvasikoiden lämmönsäätelyn fysiologiasta ja kylmässä kasvattamisen vaikutuksesta pikkuvasikoiden terveyteen, tuotantoon ja hyvinvointiin. Kirjallisuusselvitys on osa Maa- ja elintarviketalouden tutkimuskeskuksen (MTT) hallinnoimaa InnoNauta Tiedotus -hanketta. InnoNauta -hankkeet ovat saaneet rahoitusta Euroopan maaseu-dun kehittämisen Maatalousrahastosta. Tuki on myönnetty hankealueiden TE-keskusten toimesta. Hankkeiden yhteistyökumppaneina toimivat TTS tutkimus, AtriaNauta ja Valio Oy.

\section{Vasikan lämmönsäätely}

Tasalämpöiset eläimet ylläpitävät suhteellisen tasaisen ruumiinlämpötilan muuttuvissa ympäristön lämpötiloissa (Christopherson ym. 1993). Lämmönsäätely perustuu lämmöntuoton ja lämmönhukan väliseen tasapainoon, jota eläimet pitävät yllä fysikaalisen ja kemiallisen lämmönsäätelyn avulla ja jota lämmönsäätelykäyttäytyminen täydentää (Tirri ym. 1995).

Nuori vasikka ei siedä kylmää yhtä hyvin kuin aikuinen nauta, koska se tuottaa lämpöä vähemmän ja sen kudosten ja karvapeitteen tarjoama eristys on heikompi kuin aikuisella eläimellä (Gonzalez-Jimenez \& Blaxter 1962, Webster 1971). Lisäksi vasikan kylmänsietoa heikentävät suuri ihon pinta-ala suhteessa eläimen massaan sekä kehittymätön kyky säädellä vasokonstriktiota eli verisuonten supistumista (Gonzalez-Jimenez \& Blaxter 1962). Vasikan kyky sietää alhaisia lämpötiloja kehittyy vasikan kasvaessa. Kasvun myötä vasikan lämpöeristys paranee: karvapeite paksunee ja pitenee, iho paksunee ja ihonalainen rasva lisääntyy. Samalla lämmöntuotto lisääntyy (Webster 1981).

Termoneutraalialue on tasalämpöisen eläimen ympäristön lämpötila-alue, jossa eläimen ei tarvitse käyttää aineenvaihdunnallisia mekanismeja lämpötilansa säätelyyn, vaan siihen riittävät lämmönhukkaa säätelevät mekanismit (Tirri ym. 1995). Termoneutraalin alueen ylärajaa kutsutaan ylemmäksi kriittiseksi lämpötilaksi ja alarajaa alemmaksi kriittiseksi lämpötilaksi. Alempi kriittinen lämpötila on ympäristön lämpötila, jossa eläimen täytyy lisätä aineenvaihdunnallista lämmöntuottoaan säilyttääkseen lämpötasapainonsa (IUPS thermal commission 2003). Ylempi kriittinen lämpötila on ympäristön lämpötila, jossa eläimen täytyy tehostaa haihduttamalla tapahtuvaa lämmönhukkaa säilyttääkseen lämpötasapainonsa.

Termoneutraalilla alueella vasikka säilyttää ruumiinlämpönsä tasaisena fysikaalisen lämmönsäätelyn keinoin vähentämällä tai lisäämällä elimistöstä tapahtuvaa lämmönhukkaa (Davis \& Drackley 1998). Tämä tapahtuu säätelemällä iholle virtaavan veren määrää, sydämen sykettä, hengitystiheyttä ja ihon karvojen asentoa. Vasikka pienentää lämmönhukkaansa supistamalla verisuonia ruumiin ääriosissa, raajoissa ja korvissa, sekä kohottamalla ihon karvoja, jolloin syntyy eristävä ilmakerros ihon ja ulkoilman väliin.

Vasikan alempi kriittinen lämpötila on kahden ensimmäisen elinviikon aikana +9 ja $+13{ }^{\circ} \mathrm{C}$ välillä (Gonzalez-Jimenez \& Blaxter 1962, Webster 1981, Schrama ym. 1992). Vasikan kasvaessa alempi kriittinen lämpötila laskee ollen kolmen viikon iässä $+8{ }^{\circ} \mathrm{C}$ (Gonzalez-Jimenez \& Blaxter 1962) ja kuukauden iässä $0{ }^{\circ} \mathrm{C}$ (Webster 1981). Alempaan kriittiseen lämpötilaan vaikuttavat monet tekijät kuten vasikan asento, tuulennopeus sekä lattian materiaali ja kuivitus (Webster 1981, Aaltonen \& Pyykkönen 1988, Schrama ym. 1993). Vedottomuus, paksu olkipohja ja makuuasento laskevat vasikan alempaa kriittistä lämpötilaa. Hyvin energiapitoinen ruokinta lisää vasikan lämmöntuottoa ja parantaa eläimen kylmänkestävyyttä (Webster 1981). Sairaus tai riittämätön ruokinta puolestaan heikentävät vasikan kylmänkestävyyttä (Webster ym. 1978).

Ympäristön lämpötilan laskiessa vasikka lisää lämmöntuottoaan säilyttääkseen ruumiinlämpönsä tasaisena (Schrama ym. 1992, Schrama ym. 1993). Vasikalla on käytössään kaksi kemiallista keinoa lisälämmön tuottamiseksi (Davis \& Drackley 1998). Lihasvärinän avulla vasikka voi kaksinkertaistaa perusaineenvaihdunnalla tuottamansa lämmön määrän (Gonzalez-Jimenez \& Blaxter 1962). Toinen vasikan kemiallinen lämmöntuottokeino, lihasvärinätön lämmöntuotto, perustuu ruskean rasvakudoksen nopeasti tuottamaan lämpöön (Davis \& Drackley 1998).

Tunnusomaista ruskealle rasvakudokselle on elektronimikroskoopilla havaittava suuri mitokondrioiden määrä (Alexander ym. 1975). Ruskeaa rasvakudosta on pääasiassa selässä lapaluiden välissä sekä munuaisten ja suurten verisuonten ympärillä (Tirri ym. 1995). Runsaammin ruskeaa ras- 
vaa on poikasilla ja sen määrä lisääntyy ja se aktivoituu voimakkaasti eläimen joutuessa kylmään ympäristöön, jolloin se tuottaa runsaasti lämpöenergiaa. Suurin osa vastasyntyneen vasikan rasvakudoksesta on ruskeaa käsittäen noin 2,0 \% eläimen painosta (Alexander ym. 1975). Ruskea rasvakudos korvautuu vasikan ensimmäisten elinviikkojen aikana vanhemmille eläimille tyypillisellä valkealla rasvakudoksella.

Ympäristön lämpötilan noustessa ylemmän kriittinen lämpötilan yläpuolelle, vasikan täytyy käyttää energiaa lämmön poistamiseen elimistöstä (Davis \& Drackley 1998). Tämä tapahtuu pääasiallisesti tihentyneenä hengityksenä tai läähätyksenä, joiden tarkoituksena on lisätä lämmön poistumista haihtumalla. Korkeatuottoisilla naudoilla tehokas keino vähentää lämpöstressiä on vähentää rehun syöntiä. Jos eläin ei pysty säätelemään ruumiinlämpöään haihduttamalla lämpöä, ruumiinlämpö alkaa kohota ja lopulta eläin kuolee. Lämpöstressi voi vähentää väkirehun syöntiä ja heikentää kasvua kesällä syntyneillä, igluissa kasvatetuilla vasikoilla verrattuna keväällä tai syksyllä syntyneisiin vasikoihin (Broucek ym. 2008). Vasikoiden lämpöstressiä voidaan iglukasvatuksessa vähentää sijoittamalla iglut katoksen alle varjoon (Coleman ym. 1996, Spain \& Spiers 1996).

\section{Kylmään sopeutuminen}

Nautojen kyky selviytyä kylmissä olosuhteissa paranee lievän kylmänaltistuksen myötä (Young 1983). Akklimatisaatio ilmenee esimerkiksi nautojen selviytymisenä ilman lihasvärinää yhä alhaisemmista lämpötiloista talven edetessä (Gonyou ym. 1979). Kylmään sopeutuminen käsittää märehtijöillä elimistön lämpöeristyksen paranemisen, ruokahalun kasvamisen ja perusaineenvaihdunnan kiihtymisen (Young 1983). Kylmässä tapahtuva aineenvaihdunnan kiihtyminen ja lämmöntuoton lisääntyminen parantavat eläimen kykyä kestää kylmästressiä (Christopherson ym. 1993).

Lämmöntuoton lisääntyessä naudan energiantarve ja ruokahalu kasvavat (Young 1981). Kylmästressi ilmeneekin naudoilla rehusta saadun energian siirtymisenä tuotannosta tasalämpöisyyden ylläpitoon ja elimistön energiavarastojen hupenemisena (Young 1983, Christopherson ym. 1993). Kylmänaltistuksessa märehtijöiden ruuansulatuselimistön toiminnassa on havaittu muutoksia: eläimen märehtimisaktiivisuus lisääntyy, etumahojen liikkeet lisääntyvät ja ruokasulan kulku ruuansulatuskanavassa nopeutuu (Westra \& Christopherson 1976, Kennedy ym. 1977, Gonyou ym. 1979). Näistä tekijöistä johtuen rehun sulavuuden on todettu heikkenevän karkearehuvaltaisilla ruokinnoilla ympäristön lämpötilan laskiessa (Christopherson \& Kennedy 1983). Rehun viipymäajan lyhentyminen etumahoissa lyhentää aikaa, jonka rehu on alttiina pötsifermentaatiolle. Tämä haittaa etenkin hitaasti fermentoituvan kuidun sulatusta. Kylmissä oloissa havaittava lisääntynyt syönti voikin olla yhteydessä myös nopeutuneeseen ruokasulan kulkuun ruuansulatuskanavassa (Christopherson ym. 1993). Tämä teoria ei kuitenkaan päde aivan nuorilla naudoilla, joiden ruoansulatus vastaa lähinnä yksimahaisia eläimiä, koska tässä vaiheessa etumahat eivät ole vielä kehittyneet sulattamaan karkearehua.

Naudat kasvattavat uuden karvapeitteen syksyisin ja keväisin, jolloin vanha karva irtoaa uuden tieltä. Nautojen talvikarvapeite on paksumpi ulkona kuin sisällä pidetyillä naudoilla (Webster ym. 1970, Webster 1974). Syksyllä päivän pituuden lyheneminen stimuloi karvaa kasvamaan samalla, kun lämpötilan lasku vähentää karvan irtoamista (Christopherson ym. 1993). Lyhytaikaisen kylmälle altistumisen ei ole kuitenkaan havaittu saavan aikaan karvapeitteen paksunemista pikkuvasikoilla (Kauppinen 2000).

\section{Äkillinen kylmänaltistus}

Olosuhdevaihdoksen yhteydessä termisen stressin suuruus riippuu siitä, kuinka paljon uuden ympäristön lämpötilaolosuhteet poikkeavat niistä olosuhteista, joihin eläin on tottunut (Webster 1974). Lämpimässä ympäristössä pidetyt naudat kärsivät kylmästressistä, jos ne siirretään kylmään ympäristöön (Webster ym. 1970). Vastaavasti kylmään sopeutuneet naudat kärsivät lämpöstressistä, jos ne siirretään lämpimään. Akuutisti kylmälle altistettujen vasikoiden nopeasti kehittyneen hypotermian oireita ovat fyysinen heikkous, apeus, puhdittomuus, vaikeus imeä sekä haluttomuus seistä tai kävellä (Olson ym. 1980). Intensiivisen lihasvärinän aikana nauta tyypillisesti seisoo selkä kaarella (Young 1975). Lihasvärinä lakkaa vasikan ydinlämpötilan laskettua 6-8 ${ }^{\circ} \mathrm{C}$ :lla. Ruumiinlämmön edelleen laskiessa vasikka kuolee.

Vastasyntyneen vasikan karvapeite on märkä, mikä laskee karvapeitteen tarjoaman lämmöneristyksen minimiin. Etenkin kylmissä oloissa tapahtuneen poikimisen jälkeen maksimaalisen aineenvaihdunnallisen lämmöntuoton merkitys on vasikalle kriittinen normaalin ruumiinlämmön säilyttämisessä 
ja vasikan selviytymisessä (Okamoto ym. 1986). Maksimaalisessa lämmöntuottovaiheessa (summit metabolism) vastasyntynyt vasikka pystyy tuottamaan lämpöä yli kolme kertaa enemmän kuin lepoaineenvaihdunnan aikana (Okamoto ym. 1986, Robinson \& Young 1988). Vasikan energiavarastot ovat kuitenkin rajalliset, ja ne hupenevat nopeasti kylmissä olosuhteissa oleskelun pitkittyessä. On arvioitu, että $40 \mathrm{~kg}: n$ painoisessa vastasyntyneessä vasikassa on 380-600 g rasvaa ja $180 \mathrm{~g}$ glykogeenia käytettäväksi energianlähteenä (Alexander ym. 1975, Okamoto ym. 1986). Maksimaalisen lämmöntuoton ollessa käynnissä nämä energiavarastot kuluvat loppuun noin 18 tunnissa (Okamoto ym. 1986).

Eristävästä materiaalista valmistettu loimi voi lisätä vasikan kokonaiseristystä 52 prosentilla (Rawson ym. 1989a). Loimesta voi olla apua etenkin pienille tai sairaille vasikoille äkillisessä kylmänaltistuksessa. Joka sään vasikkatakin ei kuitenkaan ole havaittu parantavan yli 19 vuorokauden ikäisten ulkona (lämpötila keskimäärin $+4{ }^{\circ} \mathrm{C}$ ) kasvatettujen vasikoiden kasvua verrattuna sisällä (lämpötila keskimäärin $+6{ }^{\circ} \mathrm{C}$ ) tai ulkona ilman vasikkatakkia kasvatettujen vasikoiden kasvuun (Earley ym. 2004).

\section{Vasikoiden kylmässä kasvattamista koskeva eläinsuojelulainsäädäntö ja tukiehdot}

Eläinsuojelulainsäädännön mukaan naudat on totutettava kylmäkasvatukseen vähitellen, eikä kylmään tottumattomia eläimiä saa siirtää lämpimästä pitopaikasta suoraan kylmäkasvatukseen kylmänä vuodenaikana (MMMA 3.6.2002/6/EEO/2002.). Lisäksi lainsäädännöstä löytyy useita ympärivuotisesti ulkona kasvatettavia nautoja käsitteleviä kohtia, joita voidaan soveltaa myös vasikoiden ulkokasvatuksessa. Lainsäädännön mukaan ympärivuotisesti ulkona kasvatettavilla naudoilla on oltava asianmukaiset ruokinta- ja juoma-astiat, sulaa juomavettä sekä asianmukainen suoja epäsuotuisia sääolosuhteita vastaan, jona voi toimia esimerkiksi kolmiseinäinen rakennus (MMMA 3.6.2002/6/EEO/2002.). Säänsuojassa on oltava hyvin kuivitettu makuualue, johon kaikki eläimet mahtuvat ja pääsevät yhtä aikaa makuulle.

Eläinten hyvinvoinnin tuessa voidaan perusehtojen lisäksi valita lisäehtoja nautojen hyvinvoinnin parantamiseksi (Maaseutuvirasto 2008). Tukiehtojen mukaan ulos sijoitettavat vasikkaiglut voivat täyttää vasikkakasvatusta koskeviin lisäehtoihin (vasikoiden pito-olosuhteiden parantaminen pintaalavaatimuksilla ja vasikoiden pito-olosuhteiden parantaminen) sisältyvän karsinavaatimuksen. Lisäehdon vasikoiden pito-olosuhteiden parantaminen pinta-alavaatimuksilla mukaan vasikkaiglut voidaan hyväksyä, jos ne ovat lämmitettävissä, runsaasti kuivitettuja ja jos juoma lämmitetään kylmänä vuodenaikana. Vasikkaa ei saa pitää iglussa yksin, vaan tuen ehtojen mukaisessa ryhmässä. Ryhmäkarsinassa on jokaista korkeintaan kolmen kuukauden ikäistä vasikkaa kohti oltava pinta-alaa vähintään $1,8 \mathrm{~m}^{2}$ ja 3-6 kuukauden ikäistä vasikkaa kohti $2,1 \mathrm{~m}^{2}$. Tästä pinta-alasta on vähintään puolet oltava kiinteäpohjaista, hyvin kuivitettua, puhdasta, pitävää ja pehmeää makuualuetta. Huonetila tai sen makuualue tulee olla lämmitettävissä esimerkiksi keskuslämmityksen tai säteilylämmittimen avulla. Lisäehto vasikoiden pito-olosuhteiden parantaminen on samansisältöinen lisäehdon vasikoiden pito-olosuhteiden parantaminen pinta-alavaatimuksilla kanssa, mutta ilman pinta-alaan liittyvää ehtoa. Pinta-alan osalta lisäehdossa vasikoiden pito-olosuhteiden parantaminen noudatetaan voimassa olevan lainsäädännön määräyksiä (MMMp 23.5.1997/14/EEO/1997.).

\section{Vasikoiden kasvu, käyttäytyminen ja terveys kylmäkasvatuksessa}

Pikkuvasikoiden kasvua ja rehunkäyttöä kylmissä olosuhteissa on tutkittu melko laajasti ristiriitaisin tuloksin. Vasikat ovat kasvaneet heikommin (McKnight 1978, Scibilia ym. 1987, Bøe \& Havrevoll 1993, Scott ym. 1993, Hepola ym. 2006), yhtä hyvin (Jorgenson ym. 1970, Webster ym. 1978, Rawson ym. 1989b, Kauppinen 2000, Hepola ym. 2006) tai jopa paremmin (Richard ym. 1988, Kauppinen 2000, Gutzwiller \& Morel 2003) kylmissä kuin lämpimissä olosuhteissa. Usein kylmässä kasvatetut vasikat ovat kuitenkin myöhemmin kompensoineet alun heikomman kasvun (McKnight 1978, Richard ym. 1988, Bøe \& Havrevoll 1993). Kylmissä olosuhteissa kasvatus on lisännyt vasikoiden rehun syöntiä (McKnight 1978, Kauppinen ym. 2002) tai ei ole vaikuttanut siihen (Jorgenson ym. 1970, Hepola ym. 2006). Hansen (1984) on laskenut, että talvella vasikan rehunkulutus on 3-4 \% suurempi eristämättömässä kuin eristetyssä kasvatusympäristössä. Scibilian ym. (1987) mukaan vasikoiden ylläpitoenergiantarve on $32 \%$ suurempi kylmässä $\left(-4{ }^{\circ} \mathrm{C}\right)$ kuin lämpimässä $\left(+10^{\circ} \mathrm{C}\right)$.

Kylmissä olosuhteissa vasikoiden on havaittu lisäävän makuuaikaa ympäristön lämpötilan laskiessa (Hänninen ym. 2003) tai ympäristön lämpötila ei ole vaikuttanut vasikoiden makuulla viettämään aikaan (Bøe \& Havrevoll 1993, Kauppinen 2000). Makuulla pysytteleminen voi olla vasikan 
keino säästää energiaa, sillä makuulla vasikan tarvitsee tuottaa lämpöä vähemmän kuin seisaalla (Schrama ym. 1993). Kylmyyden on havaittu vaikuttavan nisäkkäiden uneen vähentämällä REM unen osuutta ja kokonaisnukkumisaikaa (Heller \& Glotzbach 1975).

Eläimestä tapahtuva lämmönhukka on pienin asennoissa, joissa vartalon lämpöä luovuttava pinta-ala on mahdollisimman pieni. Kylmissä olosuhteissa vasikoiden onkin havaittu makaavan vähemmän kyljellään (Hänninen ym. 2003) ja enemmän pää vartaloa vasten tuettuna (Hänninen ym. 2003) tai jalat vartalon alle sijoitettuna (ns. autohuddling) (Gonzalez-Jimenez \& Blaxter 1962, Brunsvold ym. 1985, Kauppinen 2000). Toisaalta, Bøe ja Havrevoll (1993) eivät havainneet lämpötilan vaikuttavan vasikoiden makuuasentoihin. Kylmissä oloissa vasikoiden on todettu pienentävän lämmönhukkaansa myös hakeutumalla makaamaan kiinni toiseen eläimeen (ns. allohuddling) (Bøe \& Havrevoll 1993, Kauppinen 2000).

Pikkuvasikoiden ulkokasvatusta perustellaan usein pienentyneellä tautipaineella ja terveemmillä vasikoilla (Davis ym. 1954). Ulkokasvatuksen vaikutusta vasikoiden terveyteen on tutkittu paljon. Ripulin esiintymistiheyden ja keston on raportoitu olevan juottokaudella suuntaa antavasti suurempia ulkona kuin sisällä kasvatetuilla vasikoilla (Hänninen ym. 2003). Vasikoiden todennäköisyyden tulla hoidetuksi hengitystietulehduksen tai ripulin vuoksi on todettu olevan pienempi iglukasvatuksessa kuin yksilökarsinakasvatuksessa navetassa (Waltner-Toews ym. 1986b). Vasikoiden ripulikuolleisuuden on havaittu olevan suuntaa antavasti pienempi igluissa kuin sisäyksilökarsinoissa (Gutzwiller \& Morel 2003). Kasvatuslämpötilan ei ole havaittu vaikuttavan ripulin, keuhkotulehdusten tai puhaltumisten esiintymiseen tai vasikoiden kuolleisuuteen (Jorgenson ym. 1970). Williamsin ym. (1981) havaintojen mukaan matala ruokintataso lisää ulkokasvatettujen vasikoiden kuolleisuutta. Vasikoiden kuolleisuuden on raportoitu olevani kesäkaudella pienempi iglukasvatuksessa kuin yksilökarsinakasvatuksessa navetan sisällä (Waltner-Toews ym. 1986a). Virtalan ym. (1999) mukaan iglukasvatus pienentää vasikan riskiä sairastua hengitystietulehdukseen, kun taas kasvatus aikuisten eläinten läsnä ollessa suurentaa vasikan riskiä sairastua hengitystietulehdukseen.

\section{Yhteenveto ja johtopäätökset}

Vastasyntyneen vasikan energiavarastot ovat rajalliset ja ne hupenevat nopeasti epäedullisissa olosuhteissa. Vasikoiden kyky sietää alhaisia lämpötiloja kehittyy kasvun myötä eristyksen (karvapeite, ihonalainen rasva) parantuessa ja lämmöntuoton lisääntyessä. Vasikan alempi kriittinen lämpötila on vastasyntyneenä $+9-13{ }^{\circ} \mathrm{C}$ ja kolmen viikon iässä $+8^{\circ} \mathrm{C}$. Vasikan kylmänkestävyyttä parantavat muun muassa energiapitoinen ruokinta, runsas olkikuivitus ja ympäristön vedottomuus ja kuivuus. Yleisesti nautojen pitkäaikaisessa sopeutumisessa kylmään eläimen eristys paranee, aineenvaihdunta kiihtyy ja ruokahalu kasvaa. Kylmästressi ilmenee naudoilla rehusta saadun energian siirtymisenä tuotannosta tasalämpöisyyden ylläpitoon ja kudosten energiavarastojen hupenemisena. Kylmät kasvatusolosuhteet voivat heikentää vasikan kasvua ja lisätä vasikan energiantarvetta ja rehun syöntiä. Hyvissä kylmäkasvatusolosuhteissa riittävästi ruokittujen vasikoiden kasvu ei kuitenkaan välttämättä vaarannu. Vasikat voivat vähentää lämmönhukkaansa ja säästää energiaa kylmissä olosuhteissa lisäämällä kokonaismakuuaikaa sekä makaamalla enemmän käpertyneenä ja kiinni toisessa eläimessä. Igluissa kasvatus vähentää usein eläinten riskiä sairastua ripuliin ja hengitystietulehdukseen.

\section{Suositukset ja ohjeet}

Suomen nykyisen eläinsuojelulainsäädännön mukaan kylmään tottumattomia vasikoita ei saa siirtää lämpimästä pitopaikasta suoraan kylmäkasvatukseen kylmänä vuodenaikana ilman kylmään totutusta. Kylmään totutus voidaan tehdä esimerkiksi laskemalla vähitellen ympäristön lämpötilaa tai järjestämällä aluksi lisälämpöä kylmään ympäristöön esimerkiksi säteilylämmittimen avulla. Siirron yhteydessä vasikan omaa eristystä voidaan parantaa eristävästä materiaalista valmistetulla loimella. Kylmäkasvatuksessa vasikoilla tulee olla käytössään suoja, jossa sijaitsee vedoton ja paksusti kuivitettu makuualue. Makuualuetta tulee kuivittaa riittävästi ja valumavesien pääsy makuualueelle tulee estää, jotta makuualue pysyy kuivana. Vasikoita on ruokittava riittävästi energiapitoisella rehulla. Juoma ja mielellään myös juomavesi tulee tarjota lämpiminä. Kylmäkasvatettuja vasikoita tulee tarkkailla ja hoitaa erityisen huolellisesti. Koska sairaat ja heikot vasikat ovat erityisen kylmänarkoja, ne on voitava siirtää lämpimään ympäristöön. 


\section{Kirjallisuus}

Aaltonen, R. \& Pyykkönen, M. 1988. Vetoisuus. Karjatalous 3: 16-17.

Alexander, G., Bennett, J.W. \& Gemmell, R.T. 1975. Brown adipose tissue in the new-born calf (Bos taurus). J. Physiol. 244: 223-234.

Bøe, K. \& Havrevoll, Ø. 1993. Cold housing and computer-controlled milk feeding for dairy calves: behaviour and performance. Anim. Prod. 57: 183-191.

Broucek, J., Kisac, P., Uhrincat, M., Hanus, A. \& Benc, F. 2008. Effect of high temperature on growth performance of calves maintained in outdoor hutches. J. Anim. Feed Sci. 17: 139-146.

Brunsvold, R.E., Cramer, C.O. \& Larsen, H.J. 1985. Behavior of dairy calves reared in hutches as affected by temperature. Transactions of the ASAE (American Society of Agricultural Engineers) 28: 1265-1268.

Christopherson, R.J. \& Kennedy, P.M. 1983. Effect of the thermal environment on digestion in ruminants. Can. J. Anim. Sci. 63: 477-496.

Christopherson, R.J., Kennedy, A.D., Feddes, J.J.R. \& Young, B.A. 1993. Overcoming climatic constraint. Animal production in Canada. s. 173-190.

Coleman, D.A., Moss, B.R. \& McCaskey, T.A. 1996. Supplemental shade for dairy calves reared in commercial calf hutches in a Southern climate. J. Dairy Sci. 79: 2038-2043.

Davis, C.L. \& Drackley, J.K. 1998. The development, nutrition, and management of the young calf. Iowa, Ames: Iowa State University Press. s. 79-89.

Davis, L.R., Autrey, K.M., Herlich, H. \& Hawkins, G.E. 1954. Outdoor individual portable pens compared with conventional housing for raising dairy calves J.Dairy Sci. 37: 562-570.

Earley, B., Murray, M., Farrell, J.A. \& Nolan, M. 2004. Rearing calves outdoors with and without calf jackets compared with indoor housing on calf health and live-weight performance. Ir. J. Agric. Food Res. 43: 59-67.

Gonyou, H.W., Christopherson, R.J. \& Young, B.A. 1979. Effects of cold temperature and winter conditions on some aspects of behaviour of feedlot cattle. Appl. Anim. Ethol. 5: 113-124.

Gonzalez-Jimenez, E. \& Blaxter, K.L. 1962. The metabolism and thermal regulation of calves in the first month of life. Br. J. Nutr. 16: 199-212.

Gutzwiller, A. \& Morel, I. 2003. Housing young winter born calves in hutches. Revue Suisse d'Agriculture 35 : 61-64.

Hänninen, L., Hepola, H., Rushen, J., de Passillé, A.M., Pursiainen, P., Tuure, V.-M., Syrjälä-Qvist, L., Pyykkönen, M. \& Saloniemi, H. 2003. Resting behaviour, growth and diarrhoea incidence rate of young dairy calves housed individually or in groups in warm or cold buildings. Acta Agric. Scand., Sect. A, Anim. Sci. 53: 21-28.

Hansen, K. 1984. Klimaforsøg med kalve. SjF Beretning 21. 35 s.

Heller, H.C. \& Glotzbach, S.F. 1975. Thermoregulation during sleep and hibernation. Toksessa: Robertshaw, D. (toim.). Environmental Physiology II. Baltimore, MD: University Park Press. s. 147-188.

Hepola, H., Hänninen, L., Pursiainen, P., Tuure, V.-M., Syrjälä-Qvist, L., Pyykkönen, M. \& Saloniemi, H. 2006. Feed intake and oral behaviour of dairy calves housed individually or in groups in warm or cold buildings. Livest. Sci. 105: 94-104.

IUPS thermal commission. 2003. Glossary of terms for thermal physiology. J. Therm. Biol. 28: 75-106. Jorgenson, L.J., Jorgensen, N.A., Schingoethe, D.J. \& Owens, M.J. 1970. Indoor versus outdoor calf rearing at three weaning ages. J. Dairy Sci. 53: 813-816.

Kauppinen, R. 2000. Acclimatization of dairy calves to a cold and variable micro-climate. Doctoral dissertation. Kuopio University Publications C. Natural and Environmental Sciences 113. 105 s.

Kauppinen, R., Kukkonen, S., Niemelä, P., Rissanen, A. \& Vaarala, S. 2002. Kasvatuslämpötilan vaikutus pikkuvasikoiden kasvuun ja rehunsyöntiin. Teoksessa: Marketta Rinne (toim.) Maataloustieteen Päivät 2002, Kotieläintiede, 9.-10.1.2002. Helsinki: Yliopistopaino. s. 164-167.

Kennedy, P.M., Young, B.A. \& Christopherson, R.J. 1977. Studies on the relationship between thyroid function cold acclimation and retention time of digesta in sheep. J. Anim. Sci. 45: 1084-1090.

Maaseutuvirasto. 2008. Eläinten hyvinvoinnin tuen opas, eläinten hyvinvoinnin tuki nautatilalla. $21 \mathrm{~s}$. Viitattu 5.12.2009. Saatavissa internetistä:

http://www.mavi.fi/attachments/maaseutufi/5zFFawdui/891078_nautatila_LR.pdf

McKnight, D.R. 1978. Performance of newborn dairy calves in hutch housing. Can. J. Anim. Sci. 58: 517-520.

MMMA 3.6.2002/6/EEO/2002. Maa- ja metsätalousministeriön asetus Nautojen pidolle asetettavista eläinsuojeluvaatimuksista annetun maa- ja metsätalousministeriön päätöksen muuttaminen. Annettu Helsingissä 3.6.2002. Päivitetty: 6/2002. Viitattu: 24.9.2009. Saatavissa internetistä: http:/www.mmm.fi/el/laki/F/f20m1fi.pdf .

MMMp 23.5.1997/14/EEO/1997. Maa- ja metsätalousministeriön päätös F20 nautojen pidolle asetettavat eläinsuojeluvaatimukset. Annettu Helsingissä 23.5.1997. Viitattu 24.9.2009. Saatavissa internetistä: http://www.mmm.fi/el/laki/F/f20.html .

Okamoto, M., Robinson, J.B., Christopherson, R.J. \& Young, B.A. 1986. Summit metabolism of newborn calves with and without colostrum feeding. Can. J. Anim. Sci. 66: 937-944. 
Olson, D.P., Papasian, C.J. \& Ritter, R.C. 1980. The effects of cold stress on neonatal calves. I. Clinical condition and pathological lesions. Can. J. Comp. Med. 44: 11-23.

Rawson, R.E., Dziuk, H.F., Good, A.L., Anderson, J.F., Bates, D.W. \& Ruth, G.R. 1989a. Thermal insulation of young calves exposed to cold. Can. J. Vet. Res. 53: 275-278.

Rawson, R.E., Dziuk, H.E., Good, A.L., Anderson, J.F., Bates, D.W., Ruth, G.R. \& Serfass, R.C. 1989 b. Health and metabolic responses of young calves housed at -30 degrees $\mathrm{C}$ to -8 degrees C. Can. J. Vet. Res. 53: 268-274

Richard, A.L., Muller, L.D. \& Heinrichs, A.J. 1988. Ad libitum or twice daily feeding of acidified milk replacer to calves housed individually in warm and cold environments. J. Dairy Sci.71: 2193-2202.

Robinson, J.B. \& Young, A.B. 1988. Metabolic heat production of neonatal calves during hypothermia and recovery. J. Anim. Sci. 66: 2538-2544.

Schrama, J.W., Arieli, A., Heetkamp, M.J.W. \& Verstegen, M.W.A. 1992. Responses of young calves to low ambient temperatures at two levels of feeding. Anim. Prod. 55: 397-405.

Schrama, J.W., Arieli, A., Brandsma, H.A., Luiting, P. \& Verstegen, M.W.A. 1993. Thermal requirements of young calves during standing and lying. J. Anim. Sci. 71: 3285-3292.

Scibilia, L.S., Muller, L.D., Kensinger, R.S., Sweeney, T.F. \& Shellenberger, P.R. 1987. Effect of environmental temperature and dietary fat on growth and physiological responses of newborn calves. J. Dairy Sci. 70: 1426-1433.

Scott, S.L., Christopherson, R.J., Thompson, J.R. \& Baracos, V.E. 1993. The effect of a cold environment on protein and energy metabolism in calves. Br. J. Nutr. 69: 127-139.

Spain, J.N. \& Spiers, D.E. 1996. Effects of supplemental shade on thermoregulatory response of calves to heat challenge in a hutch environment. J. Dairy Sci. 79: 639-646.

Tirri, R., Lehtonen, J., Lemmetyinen, R., Pihakaski, S. \& Portin, P. 1995. Biologian sanakirja. Keuruu: Otava. $607 \mathrm{~s}$.

Virtala, A.-M.K., Grohn, Y.T., Mechor, G.D. \& Erb, H.N. 1999. The effect of maternally derived immunoglobulin $\mathrm{G}$ on the risk of respiratory disease in heifers during the first 3 months of life. Prev. Vet. Med. 39: 2537.

Waltner-Toews, D., Martin, S.W. \& Meek, A.H. 1986a. Dairy calf management, morbidity and mortality in Ontario Holstein herds. IV. Association of management with mortality. Prev. Vet. Med. 4: 159-171.

Waltner-Toews, D., Martin, S.W. \& Meek, A.H. 1986b. Dairy calf management, morbidity and mortality in Ontario Holstein herds. III. Association of management with morbidity. Prev. Vet. Med. 4: 137-158.

Webster, A.J.F. 1981. Optimal housing criteria for ruminants. Teoksessa: Clark, J.A. (toim.). Environmental aspects of housing for animal production. Lontoo: Butterworths. s. 217-232.

Webster, A.J.F. 1974. Heat loss from cattle with particular emphasis on the effects of cold. Teoksessa: Monteith, J.L. \& Mount, L.E. (toim.). Heat loss from animals and man. London, UK: Butterworths. s. 205-231.

Webster, A.J.F. 1971. Prediction of heat losses from cattle exposed to cold outdoor environments. J. Appl. Physiol. 30: 684-690.

Webster, A.J.F., Gordon, J.G. \& McGregor, R. 1978. The cold tolerance of beef and dairy type calves in the first weeks of life. Anim. Prod. 26: 85-92.

Webster, A.J.F., Chlumecky, J. \& Young, B.A. 1970. Effects of cold environments on the energy exchanges of young beef cattle. Canadian J. Anim. Sci. 50: 89-100.

Westra, R. \& Christopherson, R.J. 1976. Effects of cold on digestibility, retention time of digesta, reticulum motility and thyroid hormones in sheep. Can. J. Anim. Sci. 56: 699-708.

Williams, P.E.V., Day, D., Raven, A.M. \& McLean, J.A. 1981. The effect of climatic housing and level of nutrition on the performance of calves. Anim. Prod. 32: 133-141.

Young, B.A. 1983. Ruminant cold stress: Effect on production. J. Anim. Sci. 57: 1601-1607.

Young, B.A. 1981. Cold stress as it affects animal production. J. Anim. Sci. 52: 154-163.

Young, B.A. 1975. Temperature-induced changes in metabolism and body weight of cattle (Bos taurus). Can. J. Physiol. Pharmacol. 53: 947-953. 